\title{
Structural and functional model of developing pedagogical skills of teachers of economics in Master's degree programmes
}

\author{
Leila Sultanova ${ }^{1, *}$, Lidiia Khomych $^{1}$, Oksana Tsiuniak $^{2}$, and Oksana Romaniuk ${ }^{3}$ \\ ${ }^{1}$ Ivan Ziaziun Institute of Pedagogical and Adult Education of the NAES of Ukraine, 9 M. Berlynskoho Str, Kyiv, 04060, Ukraine \\ ${ }^{2}$ Vasyl Stefanyk Precarpathian National University, 57 Shevchenka Str, Ivano-Frankivsk, 76018, Ukraine \\ ${ }^{3}$ Kyiv National Economic University named after Vadym Hetman, 54/1 Peremohy avenue, Kyiv, 03057, Ukraine
}

\begin{abstract}
The article represents a structural and functional development model of pedagogical skills of teachers of economic disciplines in Master's degree programmes with carrying out and proving its theoretical substantiation and the expediency of its use. The interconnected, namely theoretical, semantic and effective blocks of the suggested model are analyzed. The components, criteria and levels of pedagogical skills are described as well. The article identifies such approaches to the development of pedagogical skills of teachers of economic disciplines in Master's degree programmes, as psycho-didactic, competence, activity and innovative; the principles that must be followed in the development process of pedagogical skills of teachers of economic disciplines in Master's degree programmes, namely, professional orientation, subjectivity, priority of active teaching methods, interactive technologies and self-improvement are also characterized. The effectiveness of the structural and functional model introduction of pedagogical skills development of teachers of economic disciplines in the Master's degree programmes was tested experimentally.
\end{abstract}

\section{Introduction}

Ukraine's integration into the world educational environment requires constant improvement of the national education system, searching for the effective ways to improve the quality of educational services, development of pedagogical skills of teachers, testing and implementation of innovative pedagogical systems, real opportunities and freedom of choice in education process, education updating and organization in accordance with the world trends, ensuring the continuity of education. The transition of higher education establishments of Ukraine to a new educational paradigm along with the entry into the European educational space strengthens the requirements for professional pedagogical competence of teachers of higher education institutions. A modern teacher must have the necessary qualities and professional knowledge, be familiar with modern advances in science, and be able to navigate freely within information flows, be ready for the constant development of their pedagogical skills.

There is no sufficient professional training of future specialists to teach in higher education establishments, so the role of programmes for the development of pedagogical skills in terms of the Master's degree programmes in most non-pedagogical universities is growing.

Under today's conditions there is a need for special training of future teachers so that they can work with

*e-mail: leilasultanova22.07@gmail.com students more effectively, be successful in teaching, research and achieving personal growth as professionals.

The analysis of the experience of higher education establishments of economic profile shows: in educational activities, most of such institutions focus on the assimilation of educational material and pay less attention to preparing students for teaching economic disciplines. However, as teachers have begun to perceive and express more clearly the need to develop pedagogical skills and move in this direction, higher education establishments of economic profile recognize the need to promote the professional development of future teachers of economic disciplines.

The essence of pedagogical skills of teachers of economic disciplines lies in obtaining professional knowledge of economics, skills and abilities of teaching economic disciplines, pedagogical methods and technologies, as well as in the developed personal abilities and psychological properties that contribute to stable performance of high level pedagogical activities, timely response to changes that occur in the educational environment and adaptation to them, the presence of their own pedagogical style, the desire for personal and professional self-development. Thus, the development of pedagogical skills is recognized as a necessary part of significant professional growth.

The formation and development of pedagogical skills of teachers at higher education establishments is one of the most frequently discussed and important topics in academia. Significant influence on the development of theoretical foundations of pedagogical education and 
the development of pedagogical skills in the European and world educational space has been exerted by the research carried by H. Altrichter, A. Feldman, P. Posch, B. Somekh [1], A. Beach, M. Sorcinelli, A. Austin, J. Rivard [2], G. Kelchtermans [3], M. Kennedy [4], J. Bowen [5], J. Eyler [6], C. Haras, S. Taylor [7], K. Winter, J. Kent, R. Bradshaw [8], E. Watson [9]. The common opinion in these scientists' works is that results of scientific research should be put into practice in order to increase the level of professional and pedagogical training and the development of pedagogical skills.

We analyzed the foreign experience in the development of pedagogical skills of teachers in the United States, Canada and Western Europe. The analysis of experience revealed a set of tendencies in the development of pedagogical skills of teachers. The most prominent among them are

- the growth in the number of multidisciplinary establishments of higher education that provide training for teachers

- increasing the term of study in pedagogical educational establishments to five years,

- focusing attention on professional orientation to pedagogical specialties in the family, establishments of secondary and higher education, improving the structure, organization, forms and methods of pedagogical orientation,

- increasing the requirements for entrants to pedagogical educational establishments, developing effective forms of diagnosis and testing of personal psychophysiological characteristics, goals and motives in the process of future students selection for pedagogical specialties,

- improving the quality of pedagogical skills development programs for teachers of various specialties, taking into account modern scientific achievements related to professional along with psychological and pedagogical training of teachers,

- increase in the number of psychological and pedagogical disciplines, despite a slight decrease in the number of hours to study them in higher education, application of the principles of electiveness and integrativeness, increasing requirements for content and quality of teaching, use of intensive, developmental teaching methods,

- giving more attention to the development of future teachers' independence and activity in acquiring practical skills,

- increasing attention to the development of pedagogical skills in the system of postgraduate education.

However, despite the interest of scientists concerning the development of pedagogical skills in terms of the transition of Ukrainian higher education system to the European educational space, the problem of developing pedagogical skills of teachers of economic disciplines in modern higher education establishments is not fully covered. Therefore, the purpose of the article is a theoretical substantiation and experimental verification of the effectiveness of the structural and functional model of economic disciplines teachers' pedagogical skills development in Master's degree programmes.

Research methods to achieve this purpose:

- the method of modeling, which is essentially integrative, as it allows us to combine in pedagogical research development of pedagogical skills of teachers of economic disciplines empirical and theoretical aspects, i.e., experiment with the construction of logical structures, was applied.

- general scientific methods (analysis, synthesis, comparison, systematization, generalization) for the study of philosophical, pedagogical, psychological literature and legal basis;

- empirical methods : conversation, testing, survey and observation in order to identify the level of pedagogical skills of future teachers of economic disciplines; method of pedagogical experiment to test the effectiveness of the structural and functional model of development of pedagogical skills of teachers of economic disciplines in the conditions of Master's degree programmes;

- statistical methods: Fisher's multifunctional criterion for the purpose of levels' comparison of future teachers' of economic disciplines pedagogical skills.

\section{Results}

In order to organize the study and to improve the development process of future teachers of economic disciplines in Master's degree programmes, we have chosen the method of modeling, as one of the most effective, which is essentially integrative, as it allows us to combine empirical and theoretical aspects, i.e., an experiment with the construction of logical structures, and obtain holistic information about the object that is being under study within the pedagogical research of the development of pedagogical skills of economic disciplines teachers.

Modeling is one of the main categories of the cognition theory, as any method of scientific research is based on it both theoretical (which uses various symbolic and abstract models) and experimental (that uses subject models) [10]. Exploring the issue of modeling the competence of participants in the educational process, A. Dakhin defines the model as an artificially created object in the form of a scheme, physical structures, symbolic forms, formulas, i.e., the one, while being similar to the studied object (or phenomenon), is reflected and reproduced in a simpler form the structure, properties, links and relations between the elements of this object [11]. We can find a similar definition of a model as a sample, an instance of something; reduced reproduction of a mechanism; type, brand, design sample; schemes to explain a phenomenon or process, in the dictionary of vocational education [12].

Structural and functional models are receiving increasing attention in terms of the modern science. The structural model simulates the internal organization of the 
original. Due to the fact that structure is a way of internal organization of the object's elements, it is one of the most important aspects of anything. It is impossible to know the inner nature or the essence of objects without revealing the structure. The notion "functional model" means a model that imitates the behavior (function) of the original [13].

In the field process of research, some types can be found quite seldom in their pure form. More often mixed models are used. The proposed structural and functional model of development of pedagogical skill of teachers of economic disciplines in Master's degree programmes belongs to such type. Our choice of structural and functional model is due to the fact that the process of developing the pedagogical skills of teachers of economic disciplines is a part of a dynamic system that operates in such interrelated aspects as social and personal. Each of the components can be considered as part of another system of higher or lower level [14]. Since the pedagogical skills of teachers of economic disciplines characterize a person's professional activity, their development has a direct impact on practical, theoretical, collective and individual activities.

We should characterize the structural and functional model of development of pedagogical skill of teachers of economic disciplines in Master's degree programmes developed by us (figure 1).

The model ensures the unity of purpose, components of pedagogical skills, principles, content, forms, and methods of pedagogical skills development of teachers of economic disciplines in Master's degree programmes together with criteria and levels of their formation.

The purpose of the developed model is to ensure the positive dynamics of the development of pedagogical skills of future teachers of economic disciplines. Accordingly, the tasks are:

- to form motivation for professional and pedagogical activities and value orientations,

- to develop psychological and pedagogical competence,

- to develop organizational abilities and skills of personal interaction,

- to develop ability to do analytical activity.

We have chosen three main blocks: theoretical, content-procedural and effective. We are going to describe each of them.

The first block, theoretical, is aimed at substantiating scientific approaches and principles of development of pedagogical skills of teachers of economic disciplines in Master's degree programmes. Important dominant factors that influenced the design of our model are the theoretical foundations of pedagogical skills. The theoretical block of our model involves taking into account the initial theoretical and methodological provisions, which include psycho-didactic, competence, activity and innovation approaches.

The process of development of pedagogical skills of teachers of economic disciplines in the Master's degree programmes is, of course, a complex psychodidactic system, so the study of theoretical, pedagogical and psychological principles of the educational process, obviously, requires a psychodidactic approach.

Taking into account the competency approach in the development of pedagogical skills of teachers of economic disciplines in the Master's degree programmes ensures the development and improvement of such important qualities for future pedagogical activity as moral, value, independence, desire for self-development and self-improvement, readiness for reflection.

The activity approach is aimed at forming the activity of future teachers of economic disciplines, which contributes to the growth of independence, creativity, confidence in their abilities as well as the development of their pedagogical skills. We agree with N. Overko that the implementation of the activity approach to the development of pedagogical skills contributes to the formation of personality orientation, subjective experience, improvement of pedagogical techniques and self-regulation [15].

The current trends in education make new demands on the involvement of Master's degree programmes students in the educational process design. This determines the need for its organization, taking into account individual needs and capabilities. The task is to identify the future teacher's need for conscious learning. However, not every future teacher has a practical understanding of what he or she needs for the further growth, professional self-realization and development of pedagogical skills. Since the readiness to develop as a natural need cannot be provided from the outside, it should be formed by introducing an innovative approach, involving graduate students in more effective role models, career planning, conducting experiments that allow assessing the difference between the current state and the desired or the required level.

The principles determine the strategy and tactics of practical activity of teachers, the nature of their creative interaction in the educational process. In our model, we defined the need to comply with the following principles in the process of development of pedagogical skills of teachers of economic disciplines in the Master's degree programmes: professional orientation, subjectivity, priority of active teaching methods and interactive technologies, self-improvement.

The principle of professional orientation is based on the need for fundamental training of teachers of economic disciplines, which provides them with professional knowledge, because the teacher who does not have proper basic training cannot navigate in conditions that are objectively constantly changing. Under such conditions the competence is lost as well. One of the ways to express this principle is to combine the general scientific and methodological components of the structure of disciplines of the economic cycle. The complex of economic disciplines should provide the future teacher, on the one hand, with a modern scientific interpretation of all basic concepts and facts of the discipline, a fairly broad worldview, and, on the other hand, with knowledge of teaching methods of these disciplines. Thus, when choosing teaching methods, we give preference to those 


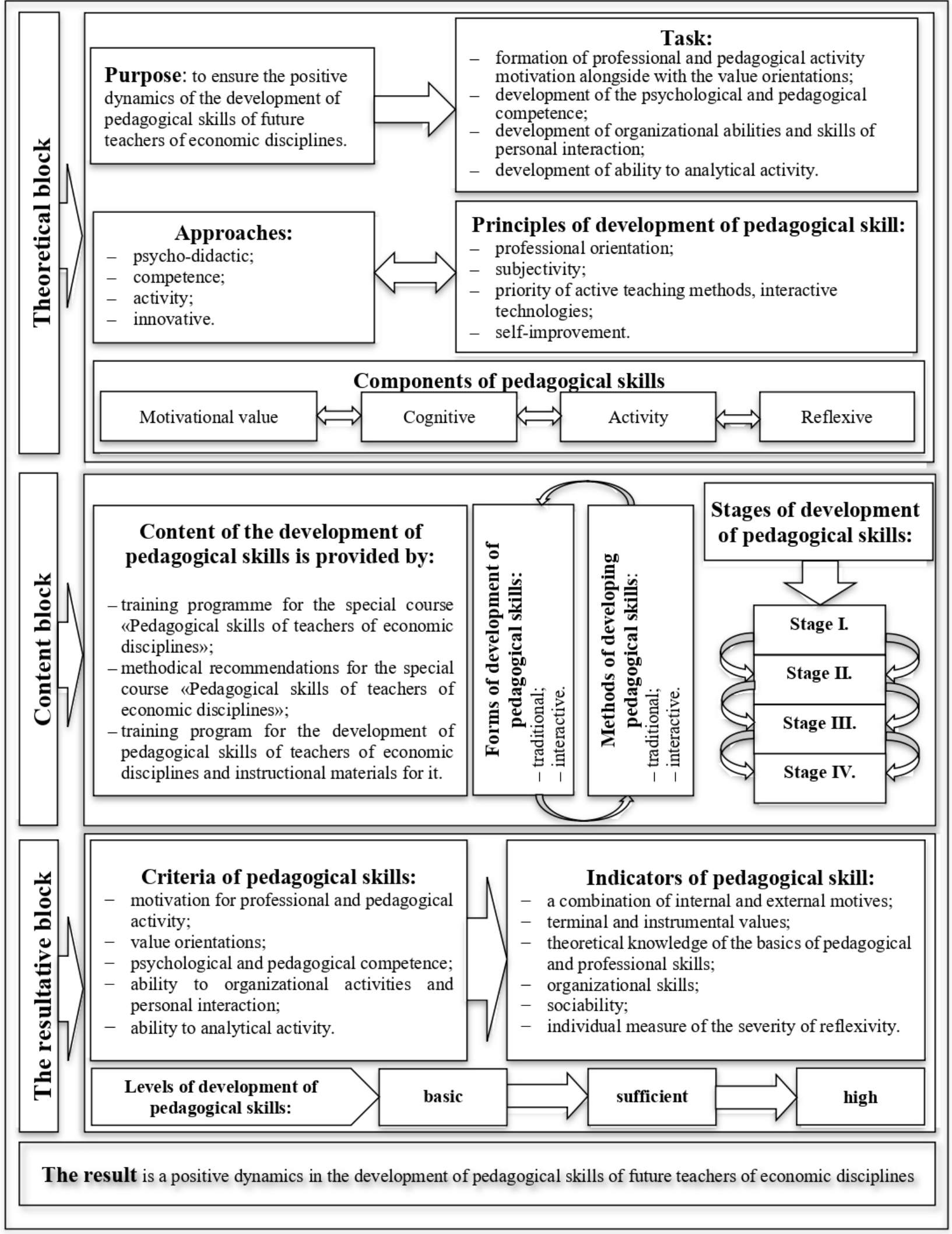

Figure 1. Structural and functional model of development of pedagogical skill of teachers of economic disciplines in the conditions of a Master's degree programmes 
methods that will be used by the future teacher. The principle of professional orientation also presupposes that all disciplines of fundamental training contribute to the acquisition by students of skills of pedagogical activity, as educational activity is leading in higher education establishments.

The principle of subjectivity recognizes the individual's right to uniqueness, inner freedom, activity and spirituality, based on the interests of the educational process and priority of personality based technologies that ensure a focus on the development of pedagogical skills of teachers of economic disciplines in Master's degree programmes which shifts the emphasis from knowledge, skills and abilities to personal progress, provides the fundamentals for the development process of pedagogical skills, which consists of elaborating its own concept of teaching economic disciplines, mastering psychological, pedagogical and management technologies, including creativity in teaching.

One of the most important areas of pedagogical skills development of teachers of economic disciplines and a prerequisite for the effective implementation of the competency approach is the introduction of active methods in the educational process of higher economic education. The principle of priority of active teaching methods and interactive technologies implies the need for the use of new educational technologies and forms of educational activities. First of all, it is the need to move from informational methods and forms of learning to active, to change orientation from knowledge to activity approach, to find opportunities to combine students' theoretical knowledge with their practical needs [16].

Implementation of self-improvement principle is possible under the conditions of mastering by future teachers of economic disciplines the ability to independently develop strategy and tactics of tasks related to educational activities, find the necessary professional information and operate it simultaneously with solving theoretical and practical problems, obtain new knowledge, necessary to achieve educational goals, search for new means of solving educational problems, formulate tasks for self-development and identify ways to implement them.

Based on a hierarchical system of principles defined by us, the model of development of pedagogical skills of teachers of economic disciplines in the Master's degree programmes is implemented through the functioning of such components of pedagogical skills as motivational value, cognitive, activity and reflexive.

Motivational value component of pedagogical skills is a structured system of personal formations, which is manifested in the value and semantic attitude to professional and pedagogical activities and desire as well as willingness to develop pedagogical skills. The cognitive component of pedagogical skills of teachers of economic disciplines is associated with a meaningful, conscious attitude to professional and pedagogical activities along with the development of pedagogical skills and involves the acquisition of the following knowledge: general theoretical, psychological and pedagogical, professional economic, that of the basics of information technology in education. The activity component of pedagogical skills takes into account the formation of organizational and communication skills among the future teachers of economic disciplines, their level of mastery of gnostic, design, methodological skills and abilities to apply them in practice. The reflexive component of pedagogical skills characterizes the teacher's knowledge and ability to analyze the phenomena of his or her own consciousness and activity. It is realized through such reflexive processes as self-understanding and understanding of others, self-evaluation and evaluation of others, self-interpretation and interpretation of others.

The semantic block of the model directly reflects the content of the development of pedagogical skills of teachers of economic disciplines in Master's degree programmes. The content of the development of pedagogical skills is provided by: the curriculum of the special course "Pedagogical skills of teachers of economic disciplines"; methodological recommendations "Development of pedagogical skills of teachers of economic disciplines"; program and instructional materials for the "Training of pedagogical skills of teachers of economic disciplines". This includes, in particular, deepening of theoretical pedagogical knowledge, improvement of practical skills and abilities of teachers, mastering of modern achievements of the advanced pedagogical experience, development of creative abilities, formation of need for constant self-improvement.

According to the content of pedagogical skills development of teachers of economic disciplines in Master's degree programmes we offer the use of various forms: traditional (lectures, practical classes, independent work, tests) and interactive (training, discussion with use of multimedia technologies, work in small groups, business game and public events).

For the development of pedagogical skills of teachers of economic disciplines in the Master's degree programmes we have proposed traditional methods (verbal, visual, practical, methods of logic content perception) and interactive methods (brainstorming, portfolio, analysis of specific situations, problem solving, game technology, game design, presentations and simulation exercises) that provide the formation and improvement of one's own teaching style and methods of economic disciplines teaching.

The dynamics of pedagogical skills development of teachers of economic disciplines in the conditions of Master's degree programmes allows reflecting the effective block of the model, developed by us, which provides the characteristics of criteria for estimating the levels of formation of teachers' pedagogical skills concerning the economic disciplines (motivation for professional and pedagogical activity; value orientations; psychological and pedagogical competence; personal interaction; ability to do analytical activities) and their indicators (combination of internal and external motives; terminal and instrumental values; theoretical knowledge of the basics of pedagogical skills and professional skills; 
organizational skills; sociability; individual measure of reflexivity).

Now we are going to characterize each of the indicators.

1. An indicator of motivation for professional and pedagogical activity is a combination of internal and external motives. Motivation for the professional and pedagogical activity is characterized by the desire for self-realization and satisfaction of professional needs; professional guidelines, values, aspirations of a high level of professional results that will lead to recognition among colleagues and students as a professional teacher; awareness of methods of encouragement, stimulation and motivation of students for studying, development of their professional orientation; willingness to take responsibility for the results of their activities.

2. The system of value orientations is characterized by the terminal and instrumental values formed in future teachers of economic disciplines. We take into account only those values that, in our opinion, are important for the effective development of pedagogical skills. These are such terminal values as the maturity of judgments; interesting professional activity; cognition (opportunity to widen one's education, general culture, intellectual development); development (work on oneself, constant physical and spiritual improvement); freedom (self-sufficiency, independence); creativity (possibility of creative activity); self-confidence (inner harmony), as well as such instrumental values as politeness (good manners); diligence (discipline); independence (ability to act independently); education (breadth of knowledge, high level of general culture); rationalism (the ability to think logically, make deliberated and rational decisions); self-control (restraint, self-discipline); courage in defending one's opinion; tolerance for the views and opinions of others; breadth of views (the ability to understand a different point of view, respect other tastes, customs and habits).

3. Indicators of psychological and pedagogical competence are theoretical knowledge of the basics of pedagogical and professional skills that future teachers acquire, namely, understanding of the peculiarities of curricula framing and the ability to apply knowledge about relevant factors and processes for decision-making concerning the academic plan; understanding of the relationship between the assessment and teaching along with the ability to use formal and informal assessment in order to understand the students better; planning of the educational process; control of the understanding of the content of educational material along with making changes in teaching activity; awareness of different evaluation strategies, ability to analyze evaluation results; understanding of different approaches to pedagogical activity and ways of applying them for assistance of educational activity of students; awareness of educational material which includes the teaching methods peculiarities that contribute to a better understanding of its content; ability to apply appropriate teaching methods in order to develop competence in the field of science that is being studied as well as to analyze gaps in students' understanding of the material content in order to improve teaching; understanding of the principles and procedures of the classes organization and the ability to apply such knowledge for the development of educational activities of students and help them to achieve better results considering their educational goals; understanding of external and internal motivation, the relationship between motivation and students' achievements, strategies, principles and practical methods of motivation and ways to effectively apply such principles and methods to promote active students' participation in learning; acquisition of the new information, development of their self-motivation and independence; understanding of the basics of communication theory; awareness of the ways to improve professional knowledge, skills and abilities and the development of pedagogical skills.

4. Organizational skills and sociability are indicators of the ability to do organizational activities and personal interaction of the future teachers. Organizational skills are manifested in the rapidity of orientation in difficult situations, initiative, ability to anticipate the consequences of their actions, endurance, demanding, propensity to organizational activities, independence, self-criticism, attitude to social activity, ability to project student personality in the process of education, ability to unite students and direct them towards performing socially significant tasks, the ability to distribute attention between several activities simultaneously. Sociability is manifested within the ability of an individual to establish, sustain and maintain good personal and business relationships with others, tact, ability to express their thoughts and expressions through verbal and nonverbal means, the ability to formulate a problem, present material in an accessible form, arouse cognitive interest in learning disciplines, in understanding the psychology of the student, mastering the techniques of emotional and volitional influence on students.

5. An indicator of the ability to do analytical activity is an individual measure of the reflexivity manifestation. Reflexivity is manifested in the ability to realize one's motives, goals, mental and emotional state in a situation of choosing a style of behavior and on this basis to build a strategy for their activities. Professionally oriented critical thinking includes professional intelligence, culture of professional thinking, ability to identify laws, principles and rules of professional and pedagogical 
activity, analysis, forecasting, designing, planning of self-development in the context of general and professional culture; developed professional memory, which provides not only the preservation of meaningful information, but also its active mental processing, establishing logical and associative connections, verbal thinking, ability to make verbal analogies, erudition and the ability to hold constructive professional dialogue. The ability to do analytical activities is characterized by breadth and flexibility of thinking, objectivity, comprehensive consideration of problems, and awareness of ways to apply the accumulated theoretical basis in practice.

The pedagogical skills of future teachers of economics are characterized by three levels (basic, sufficient and high), which will allow us to compare the predicted and obtained results of diagnosis and adjustment of this process.

Results of the experimental study confirmed the effectiveness of our substantiated structural and functional model of pedagogical skills development of economic disciplines teachers in Master's degree programmes. To conduct the experiment, we created a program and research plan; the required number of participants in the experimental study was determined; the criteria were selected and substantiated. The experimental study involved three stages: ascertaining, formative and generalizing.

The ascertaining experiment was conducted on the basis of Kyiv National Economic University named after Vadym Hetman, State University of Economics and Technology, Kherson National Technical University. At different stages of the study, 250 students at the second (the Master's) level of higher education in economic specialities took part in the experiment.

Determining the level of development of pedagogical skills of respondents of control and experimental groups to the formative experiment was carried out using a set of methods: the method of determining the motivation of professional activity (K. Zamfir modified by A. Rean; "Value orientations" by M. Rokych; the author's test to identify the level of psychological and pedagogical competence of future teachers of economics, rapid diagnosis of organizational skills M. Fetiskin, V. Kozlov, H. Manuilov; methods of assessing the level of sociability by V. Riakhovsky and methods of diagnosis of individual reflexivity manifestation by A. Karpov (table 1)).

We performed a qualitative and quantitative analysis of the input diagnosis results and determined the levels of pedagogical skills of future teachers of economic disciplines. The analysis of the results of the observational experiment showed the predominance of basic $(25.6 \%$ of people) and sufficient (48\% of people) levels of development of pedagogical skills. This gave grounds to conclude that at the present stage of development of higher economic education there is a need to create more effective mechanisms for training and development of pedagogical skills of future teachers of economic disciplines in the Master's degree programmes by means of improving the content, forms and methods for organizing this process, implementation of programs for the development of pedagogical skills in terms of Master's degree programmes aimed at preparing future teachers of economic disciplines for the introduction of modern leading pedagogical technologies and the formation along with development of their own pedagogical style.

Improving the level of pedagogical skills was carried out at the formative stage of the experiment through the introduction of the proposed content, forms and methods of their development in the Master's degree programmes. The curriculum of the special course "Pedagogical skills of teachers of economic disciplines" in the educational process of higher education establishments for students at the second (the Master's) level of higher education in economic specialties was introduced; methodological recommendations for the special course "Pedagogical skills of teachers of economic disciplines" and pedagogical skills development training program for teachers of economic disciplines and instructive-methodological materials to it were implemented as well. Implementation was carried out by using traditional and interactive forms and methods of pedagogical skills development'.

At the generalizing stage of the research, the results of the diagnosis in the experimental group revealed positive changes in the levels of development of pedagogical skills of future teachers of economic disciplines (figure 2).

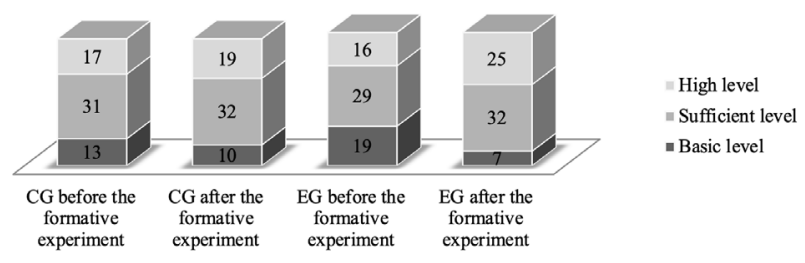

Figure 2. Dynamics of the future teachers of economic disciplines pedagogical skills development before and after the formative experiment

The number of respondents in the experimental group with a basic level of pedagogical skills has more than halved: from 19 people (29.69\%) to 7 people (10.94\%). The changes have also occurred in the number of future teachers who have a sufficient level of pedagogical skills. The number of such people increased from 29 people (45.31\%) to 32 people $(50 \%)$. More significant changes were found in the number of people with a high level of pedagogical skills. Participants in the experiment with a high level of pedagogical skills before the formative experiment of the study were 16 people $(25 \%)$ and after the formative experiment were 25 people $(39.06 \%)$.

In order to compare the results of the identified levels of future economics teachers' pedagogical skills, we used the multifunctional Fisher's test. Thus, the indicator $\left(\varphi_{\text {empirical }}\right)$ of sufficient and high levels of pedagogical skills of the experimental group before and after the formative experiment is equal to 2.72 , which 
Table 1. Levels of pedagogical skills before the formative experiment

\begin{tabular}{|c|c|c|c|c|c|c|c|}
\hline \multirow{3}{*}{ № } & \multirow[b]{3}{*}{ tors } & \multicolumn{2}{|c|}{ Basic } & \multicolumn{2}{|c|}{ Sufficient } & \multicolumn{2}{|c|}{ High } \\
\hline & & $\begin{array}{c}\text { CG } \\
\text { (61 people) }\end{array}$ & $\begin{array}{c}\text { EG } \\
\text { (64 people) }\end{array}$ & $\begin{array}{c}\text { CG } \\
\text { (61 people) }\end{array}$ & $\begin{array}{c}\text { EG } \\
\text { (64 people) }\end{array}$ & $\begin{array}{c}\text { CG } \\
\text { (61 people) }\end{array}$ & $\begin{array}{c}\text { EG } \\
\text { (64 people) }\end{array}$ \\
\hline & & $\begin{array}{c}\text { Quantity } \\
(\%)\end{array}$ & $\begin{array}{c}\text { Quantity } \\
(\%)\end{array}$ & $\begin{array}{c}\text { Quantity } \\
(\%)\end{array}$ & $\begin{array}{l}\text { Quantity } \\
(\%)\end{array}$ & $\begin{array}{c}\text { Quantity } \\
(\%)\end{array}$ & $\begin{array}{c}\text { Quantity } \\
(\%)\end{array}$ \\
\hline 1. & $\begin{array}{l}\text { A combination of } \\
\text { internal and external } \\
\text { motives }\end{array}$ & $\begin{array}{c}5 \\
(8,2)\end{array}$ & $\begin{array}{c}13 \\
(20,3)\end{array}$ & $\begin{array}{c}15 \\
(24,6)\end{array}$ & $\begin{array}{c}13 \\
(20,3)\end{array}$ & $\begin{array}{c}41 \\
(67,2)\end{array}$ & $\begin{array}{c}38 \\
(59,4)\end{array}$ \\
\hline 2. & $\begin{array}{l}\text { Terminal and } \\
\text { instrumental values }\end{array}$ & $\begin{array}{c}19 \\
(31,2)\end{array}$ & $\begin{array}{c}28 \\
(43,8)\end{array}$ & $\begin{array}{c}36 \\
(59,0)\end{array}$ & $\begin{array}{c}33 \\
(51,6)\end{array}$ & $\begin{array}{c}6 \\
(9,8)\end{array}$ & $\begin{array}{c}3 \\
(4,6)\end{array}$ \\
\hline 3. & $\begin{array}{l}\text { Theoretical } \\
\text { knowledge of the } \\
\text { basics of pedagogical } \\
\text { and professional skills }\end{array}$ & $\begin{array}{c}28 \\
(45,9)\end{array}$ & $\begin{array}{c}29 \\
(45,3)\end{array}$ & $\begin{array}{c}28 \\
(45,9)\end{array}$ & $\begin{array}{c}30 \\
(46,9)\end{array}$ & $\begin{array}{c}5 \\
(8,2)\end{array}$ & $\begin{array}{c}5 \\
(7,8)\end{array}$ \\
\hline 4. & Organizational skills & $\begin{array}{c}8 \\
(13,1)\end{array}$ & $\begin{array}{c}9 \\
(14,0)\end{array}$ & $\begin{array}{c}37 \\
(60,7)\end{array}$ & $\begin{array}{c}38 \\
(59,4)\end{array}$ & $\begin{array}{c}16 \\
(26,2)\end{array}$ & $\begin{array}{c}17 \\
(26,6)\end{array}$ \\
\hline 5. & Sociability & $\begin{array}{c}4 \\
(6,6)\end{array}$ & $\begin{array}{c}8 \\
(12,5)\end{array}$ & $\begin{array}{c}27 \\
(44,3)\end{array}$ & $\begin{array}{c}24 \\
(37,5)\end{array}$ & $\begin{array}{c}30 \\
(49,2)\end{array}$ & $\begin{array}{c}32 \\
(50,0)\end{array}$ \\
\hline 6. & $\begin{array}{l}\text { Individual measure of } \\
\text { the severity of } \\
\text { reflexivity }\end{array}$ & $\begin{array}{c}12 \\
(19,7)\end{array}$ & $\begin{array}{c}28 \\
(43,8)\end{array}$ & $\begin{array}{c}44 \\
(72,1)\end{array}$ & $\begin{array}{c}33 \\
(51,6)\end{array}$ & $\begin{array}{c}5 \\
(8,2)\end{array}$ & $\begin{array}{c}3 \\
(4,6)\end{array}$ \\
\hline & $\begin{array}{l}\text { ithmetic mean of } \\
\text { gical skills }\end{array}$ & $\begin{array}{c}13 \\
(21,3)\end{array}$ & $\begin{array}{c}19 \\
(29,7)\end{array}$ & $\begin{array}{c}31 \\
(50,8)\end{array}$ & $\begin{array}{c}29 \\
(45,3)\end{array}$ & $\begin{array}{c}17 \\
(27,9)\end{array}$ & $\begin{array}{c}16 \\
(25,0)\end{array}$ \\
\hline
\end{tabular}

is more than the critical value $\left(\varphi_{\text {critical }}=2.31\right)$ of the level of statistical significance accepted in psychology. Comparison of the percentage of study participants with high and sufficient levels of development of pedagogical skills in the experimental group before and after the formative stage of the pedagogical experiment made it possible to prove the reliability of the results.

\section{Conclusion}

The modern system of professional training of economic specialists for teaching activities consists of the insufficiently developed mechanisms for the development of pedagogical skills. This necessitated the further development of the studied quality improvement model.

The structural and functional model of pedagogical skills development of teachers of economic disciplines in Master's degree programmes that was substantiated and developed by us, includes the definitions of the purpose, tasks, the theoretical block, the semantic block and also the feedback mechanism reflected in the effective block. The structure of the model is based on the logic of the studied process: from the existing initial state of formation of the basics of pedagogical skills to purposeful gradual achievement by future teachers of a higher level of pedagogical skills, so it allows testing the effectiveness of Master's degree programmes conditions experimentally. The expected increase in the level of economics teachers' pedagogical skills will motivate them further succeed, expand their professional worldview, develop creativity and critical consideration of organization of the educational process in higher economic education establishments. The introduction of the proposed structural and functional model of pedagogical skills development in the Master's degree programmes makes it possible to form the pedagogical competence of teachers of economic disciplines, which is the integration of theoretical knowledge, practical skills and important personal qualities of the teacher.

\section{References}

[1] H. Altricher, A. Feldman, P. Posch, B. Somekh, Teachers investigate their work: An introduction to action research across the professions (Routledge, London \& New York, 2008)

[2] A.L. Beach, M.D. Sorcinelli, A.E. Austin, J.K. Rivard, Faculty development in the age of evidence: Current practices, future imperatives (Stylus Publishing, LLC, Sterling, VA, 2016)

[3] G. Kelchtermans, Teachers and Teaching: theory and practice 21, 361 (2015)

[4] M. Kennedy, Review of Educational Research 86, 945 (2016)

[5] J.A. Bowen, C.E. Watson, Teaching Naked Techniques: A Practical Guide to Designing Better Classes (Jossey-Bass, San Francisco, CA, 2017)

[6] J. Eyler, How Humans Learn: The Science and Stories Behind Effective College Teaching, Teaching and Learning in Highe (West Virginia University Press, Morgantown, WV, 2018), ISBN 9781946684653

[7] C. Haras, S. Taylor, M. Sorcinelli, L. Von Hoene, Institutional Commitment to Teaching Excellence: Assessing the Impacts and Outcomes of Faculty Development (American Council on Education, Washington, DC, 2017)

[8] K. Winter, J. Kent, R. Bradshaw, Preparing Future Faculty: A Framework for Program Design and 
Evaluation at the University Level (Council of Graduate Schools, Washington, DC, 2018)

[9] E. Watson, Peer Review: Faculty Development for Self-Renewal 21 (2019)

[10] M. Soldatenko, Teoretyko-metodolohichni osnovy rozvytku samostiinoi piznavalnoi diialnosti maibutnoho vchytelia (2007)

[11] A. Dakhin, Modelirovanie kompetentnosti uchastnikov otkryitogo obschego obrazovaniya (2012)

[12] S. Honcharenko, I. Ziaziun, N. Nychkalo, Profesiina osvita: slovnyk: navchalnyi posibnyk (Vyshcha shkola, Kyiv, 2000)
[13] L. Sultanova, Teoretychni i metodychni zasady polikulturnoi osvity maibutnoho vykladacha vyshchoho pedahohichnoho navchalnoho zakladu (2018)

[14] O. Romaniuk, Hirska shkola Ukrainskykh Karpat 19 (2018)

[15] N. Overko, Rozvytok pedahohichnoi maisternosti vykladachiv spetsialnykh dystsyplin profesiino-tekhnichnykh navchalnykh zakladiv kulinarnoho profiliu u protsesi pidvyshchennia kvalifikatsii (2018)

[16] L. Naumov, Uchebnye igry v medicine (Medicina, Tashkent, 1986) 